\title{
Role of Diet in Ayurvedic Treatise as Perceived by Ayurvedic Doctors
}

\author{
Divya Shukla* and Vibha Bhatnagar \\ Department of Foods \& Nutrition, College of Home Science, Maharana Pratap \\ University of Agriculture and Technology, Udaipur, Rajasthan, India \\ *E-mail: divyashukla8@ rediffmail.com
}

KEYWORDS Ayurveda; health care; diet; life style; traditional system

\begin{abstract}
Ayurveda is a component of health care having a traditional system of medicines. The basic principle of Ayurveda is to prevent illness by maintaining balance in the body, mind, and consciousness through proper drinking, diet and lifestyle, as well as herbal remedies. A study on the role of diet in Ayurvedic treatise was undertaken. An attempt was also made to find out the existing diet counseling practices, barriers and suggestions for improvement. For the purpose, fifty Ayurvedic practitioners serving in two government Ayurvedic hospitals of Udaipur city Rajasthan were selected. The information was collected with the help of an interview schedule. Majority of the respondents were of the opinion that diarrhea, hypertension, peptic-ulcer, tuberculosis, hepatitis and typhoid are the diseases for which the diet- drug therapy is the most appropriate mode of the treatment where as obesity can be cured by dietary modifications coupled with physical exercise. All the Ayurvedic doctors agreed with need for improving nutrition counseling practices and recommended to include more nutrition courses in Ayurvedic curriculum and need for appointing dietitian in Ayurvedic hospital was also suggested.
\end{abstract}

\section{INTRODUCTION}

Food is a basic need of man and life cannot be sustained without adequate nutrition. The physiological need for food is actually the need for nutrients which are needed for the body's growth, maintenance, repair and reproduction. (Kataria, 1996). Morbid or diseased state of any human being leads to alteration in digestive system and hence is unable to consume the normal diet. Thus the diet of an ill person has to be suitably modified with some foods being restricted (perhez - the term used in day to day language) (Khanna, 1997).

There are various ways of treating particular diseases viz. Allopathy, Ayurveda, Homeopathy, Naturopathy, Electro homeopathy, Accupressure etc. and the most common among these is Allopathy. Allopathic treatment is mainly based on use of drugs and less importance is paid on the role of diet. However in recent times, the risks of side effects of allopathic medicines is now being realized and people are opting for other modes of treatment and Ayurveda therapy is one of the preference next to Allopathy and is becoming popular in western cultures also.

Ayurveda is a holistic approach to health that is designed to help people live long, healthy, and well-balanced lives. Ayurveda is a component of health care having a traditional system of medicines. The basic principle of Ayurveda is to prevent illness by maintaining balance in the body, mind, and consciousness through proper drinking, diet and lifestyle, as well as herbal remedies. (Chopra and Doiphose, 2002).

According to Ayurvedic beliefs, each person has a distinct pattern of energy- a specific combination of physical, mental and emotional characteristics. It is also believed that there are three basic energy types called doshas viz vata, pitta and kaph present in every person. Ayurvedic practitioners prescribe treatments designed to bring the doshas back into balance. In almost all diseases Ayurveda has advised the avoidance of certain food items (perhez), which have a tendency to aggravate the disease and consumption of certain food items that have a beneficial effect or the recovering from the disease. It is well accepted that by and large the curriculum of medical school give little or negligible importance to science of nutrition and dietetics (Olson, 1979; Young, 1983; Emes, 1994). This investigation was thus performed to evaluate the current awareness amongst 50 Ayurvedic doctors regarding the role of nutrition in general and use of certain specific diets in particular disease syndromes.

\section{MATERIAL AND METHODOLOGY}

The present study was undertaken in two 
purposively selected government Ayurvedic Hospitals of Udaipur City i.e. Madan Mohan Malviya Hospital and Motichohatta Ayurvedic Hospitals of Udaipur City during November 2003March 2004.

A sample of 50 Ayurvedic doctors having minimum 2 years of experiences were selected on the basis of willingness and availability at the time of study. An interview schedule was designed and questions were included to get answers on the following a) background profile of the respondents, b) questions regarding the knowledge of two food items to be included and two food items to be excluded for each of the diseased state viz typhoid, tuberculosis, diarrhea, constipation, peptic ulcer, underweight, obesity, hypertension, heart attack, diabetes mellitus, hepatitis, kidney stones. C) type of special diet recommended for treating diseases and existing dietary counseling practices and their opinion/ attitudes towards diet counseling

\section{RESULT AND DISCUSSION}

Background Profile: The information gathered from individual respondents about their sex, age, religion, food habits, length of the service, educational qualification and experience has been suitably classified to have a clear picture of the population under study. The results are presented in table 1 .

Regarding the age group it was found that 40 percent of the respondents belonged to $50-60$ years of age groups, followed by 38 percent and 28 percent of the respondents in the age group of 40-50 and 30-40 year, respectively. Majority of

Table 1: Background profile of the Ayurvedic doctors

\begin{tabular}{lcc}
\hline & $\begin{array}{c}\text { No. of Respondents } \\
(N=50)\end{array}$ & $\begin{array}{c}\text { Percentage } \\
(\%)\end{array}$ \\
\hline Age Group & & \\
$30-40$ & 11 & 22 \\
$40-50$ & 19 & 38 \\
$50-60$ & 20 & 40 \\
Sex & & \\
Male & 37 & 74 \\
Female & 13 & 26 \\
Length of the Service & & \\
$4-10$ yrs. & 8 & 16 \\
11-19 yrs. & 23 & 46 \\
20-28 yrs. & 19 & 38 \\
Educational Qualifications & & \\
Under graduate (B.A.M.S.) & 18 & 36 \\
Post Graduate (M.D.) & 24 & 48 \\
Ph.D. & 8 & 16 \\
\hline
\end{tabular}

the respondents (74\%) were males and remaining 26 percent were females. When classified on the basis of food habits, it was found that almost all the respondents (98\%) were vegetarians and only one respondent $(2 \%)$ was non-vegetarian. Less than half of the respondents $(46 \%)$ had the experience of 11-19 years. Similarly 38 percent were in the job for 20 to 28 years. Very few (16\%) respondents had experience of 4 to 10 years. The Table 1, further shows that 48 percent respondents were post graduate (M.D.) where as only 36 percent of the respondents were undergraduate (B.A.M.S.) and very few respondents i.e., 16 percent had achieved a highest degree of qualification that in Ph.D. All the respondents belonged to Hindu religion.

Inclusion/Exclusion of Food Items in Diseases: In the present study the Ayurvedic doctors were also probed to assess their knowledge about various food items that should be included or excluded during various diseased conditions. An insight into the data presented in table 2 explicit that a good proportion of study subjects (>74\%) accentuated the inclusion of milk and eggs in Typhoid while, 50 percent respondents knew that whole grains, owing to its high fiber content, should be totally excluded to prevent intestinal irritation and 60 percent of them suggested for partial inclusion of refined cooked cereals.

The significance of liberal intake of milk and dhal in the diet of an individual suffering from tuberculosis was known to more than 48 percent Ayurvedic doctors whereas for the exclusion of fatty meat (48\%), tea coffee $(68 \%)$ their knowledge was below satisfactory. It can further be discerned from the table that the awareness of the study subjects about inclusion of all food items but skimmed milk powder in diet during gastro intestinal disturbances viz, diarrhea, constipation and peptic ulcer was good. The need for avoiding pickles and chutney by an ulcerative patient was correctly recognized by 48 percent respondents. However, other food items to be excluded during these conditions were in the knowledge of less than half the study population.

The correct knowledge regarding the necessity of including sufficient amount of cereals and pulses in the diet of an underweight person was reflected in the answer of most of the subjects while 86 and 46 percent of them recommended cakes/pastries and vegetable salad. The intake of nuts-oil seeds and alcoholic beverages was prohibited for obese individual 
by 80 and 74 percent respectively. Further, less than 64 percent respondents allowed inclusion of whole grains and exclusion of whole Milk. Unlike other diseases the knowledge of Ayurvedic doctors about various dietary modifications requisite in hypertensive condition was excellent.

Despite of the significant role, fat plays in managing cardiovascular diseases only about 30 percent Ayurvedic doctors proposed for inclusion of vegetable oil. However majority of them were familiar and hence recommended inclusion of whole grains, fruits and vegetable.

The table 2, also show that majority of respondents though were aware that diabetes mellitus restricts the use of refined sugars, but they were found to be ignorant of the fact that complex carbohydrates, squashes and canned foods having sugar as main ingredient should also be included or excluded. The knowledge of inclusion of fruits-leafy vegetable was possessed by more than eighty percent respectively. Further, 52 and 86 percentage of study Ayurvedic doctors responded correctly that fruits, eggs, cereal and pulses can be included in patient's diet having kidney stones, but milk in restricted amount was suggested by 30 percentages. In case of hepatitis, 60 percent respondents, with equal representation from the two sectors, recommended inclusion of sugar and jaggery, while 54 percent respondents knew that of protein beverages, exactly equal number of respondents $(44 \%)$ gave correct answer for nuts-oil seeds and milk.

In another study by Suneja and Bhatt (1985) it was found that the medical practitioners of Hissar district could not point out specific foods to be included or omitted from the diets of individuals with peptic ulcer, diarrhea and hypertension while their Udaipur counterparts were better aware.

Ayurvedic doctors (40 and $64 \%$ ) recommended either to increase the doctor to patient ratio and/or to include more courses in Ayurvedic curriculum. The need of a nutrition expert for teaching nutrition was acknowledged by eighty six per cent Ayurvedic doctors. Similarly Langseth and Gemson (1992) reported that $68 \%$ of interviewed physicians accepted that they had not received adequate nutritional training in medical schools. Reports emphasized inclusion of nutrition education both in basic as well as clinical sciences because these courses focused on nutrition will have a definite support to a systematic and integrated approach to health care system. This knowledge should regularly be updated using
Table 2: Knowledge of respondents about the food items to be included/excluded during various diseases

\begin{tabular}{|c|c|c|c|c|}
\hline$S$ & Diseases & Food & Respon-1 & ercen \\
\hline No. & & Items & $\begin{array}{c}\text { dents } \\
(n=50)\end{array}$ & $\begin{array}{l}\text { tage } \\
(\%)\end{array}$ \\
\hline 1 & Typhoid & Milk & 42 & 84 \\
\hline & & Egg & 37 & 74 \\
\hline & & Whole grain & 25 & 50 \\
\hline & & $\begin{array}{l}\text { Refined cooked } \\
\text { cereals }\end{array}$ & 30 & 60 \\
\hline 2 & Tuberculosis & Milk & 48 & 96 \\
\hline & & Dhal & 48 & 96 \\
\hline & & Fatty Meat & 24 & 48 \\
\hline & & Tea and Coffee & 34 & 68 \\
\hline 3 & Diarrhea & $\begin{array}{l}\text { Strained Fruit } \\
\text { Juices }\end{array}$ & 42 & 84 \\
\hline & & $\begin{array}{l}\text { Skimmed Milk } \\
\text { Powder }\end{array}$ & 29 & 58 \\
\hline & & $\begin{array}{l}\text { Nuts and } \\
\text { Oil seeds }\end{array}$ & 38 & 76 \\
\hline & & Whole grains & 24 & 48 \\
\hline 4 & Constipation & $\begin{array}{l}\text { Raw vegetable } \\
\text { and Fruits }\end{array}$ & 47 & 94 \\
\hline & & Whole grains & 38 & 76 \\
\hline & & Refined Flour & 41 & 82 \\
\hline & & Tea and Coffee & 38 & 76 \\
\hline 5 & Peptic Ulcer & Milk and Cream & 48 & 96 \\
\hline & & Bread & 27 & 54 \\
\hline & & Whole grain & 29 & 58 \\
\hline & & $\begin{array}{l}\text { Pickles and } \\
\text { chutney }\end{array}$ & 48 & 96 \\
\hline 6 & Under weight & $\begin{array}{l}\text { Cereal and cereal } \\
\text { products }\end{array}$ & 48 & 96 \\
\hline & & Pluses & 46 & 92 \\
\hline & & $\begin{array}{l}\text { Cakes and } \\
\text { Pastries }\end{array}$ & 42 & 84 \\
\hline & & Vegetable salad & 23 & 46 \\
\hline 7 & Obesity & Whole grain & 32 & 64 \\
\hline & & Whole Milk & 25 & 50 \\
\hline & & $\begin{array}{l}\text { Nuts and } \\
\text { Oil seeds }\end{array}$ & 40 & 80 \\
\hline & & $\begin{array}{l}\text { Alcoholic } \\
\text { Beverages }\end{array}$ & 37 & \\
\hline 8 & Hypertension & Cereal and Pulses & 47 & 74 \\
\hline & & Fruits & 41 & 82 \\
\hline & & Bread and Biscuit & 37 & 74 \\
\hline & & Papad & 47 & 94 \\
\hline 9 & Heart Attack & $\begin{array}{l}\text { Hydro generated } \\
\text { fat }\end{array}$ & 37 & 74 \\
\hline & & Vegetable Oil & 15 & 30 \\
\hline & & $\begin{array}{l}\text { Fruits and leafy } \\
\text { vegetable }\end{array}$ & 48 & 96 \\
\hline & & Whole grains & 30 & 60 \\
\hline 10 & Diabetes & Refined Sugars & 29 & 54 \\
\hline & Mellitus & Complex C̆HO & 9 & 18 \\
\hline & & $\begin{array}{l}\text { Fruits and leafy } \\
\text { vegetables }\end{array}$ & 40 & 80 \\
\hline & & $\begin{array}{l}\text { Squashed and } \\
\text { canned foods }\end{array}$ & 39 & 78 \\
\hline 11 & Hepatitis & Protein Beverages & 27 & 54 \\
\hline & & Milk & 22 & 44 \\
\hline & & Sugar and Jaggery & 30 & 60 \\
\hline & & Nuts and Oil seeds & 22 & 44 \\
\hline 12 & Kidney & Milk & 33 & 66 \\
\hline & Stones & Fruits & 43 & 86 \\
\hline & & Eggs & 20 & 40 \\
\hline & & Cereals and Pulses & 26 & 52 \\
\hline
\end{tabular}


Table 3: Suggestions of Ayurvedic doctors for improving counseling practice

\begin{tabular}{lcc}
\hline & $\begin{array}{c}\text { Ayurvedic } \\
\text { doctors } \\
(n=50)\end{array}$ & $\begin{array}{c}\text { Percen- } \\
\text { tage } \\
(\%)\end{array}$ \\
\hline $\begin{array}{l}\text { Ayurvedic Therapy should } \\
\text { emphasize nutrition education }\end{array}$ & 44 & 88 \\
$\begin{array}{l}\text { More courses in Ayurvedic curriculum } \\
\text { Nutrition expert for teaching }\end{array}$ & 32 & 64 \\
$\begin{array}{l}\text { Increase doctor to patient ratio } \\
\text { Participation in seminars meetings }\end{array}$ & 20 & 87 \\
$\quad$ and symposium & 40 \\
Mass media effective disseminator & 45 & 94 \\
\hline
\end{tabular}

Table 4: Responsibility of Nutrition counseling as perceived by Ayurvedic doctors

\begin{tabular}{lcc}
\hline & $\begin{array}{c}\text { Ayurvedic } \\
\text { doctors } \\
(n=50)\end{array}$ & $\begin{array}{c}\text { Percen- } \\
\text { tage } \\
(\%)\end{array}$ \\
\hline $\begin{array}{l}\text { Ayurvedic doctors sole } \\
\text { responsibility }\end{array}$ & 22 & 44 \\
$\begin{array}{l}\text { Dietitian's at block level } \\
\text { Co-operation between }\end{array} \quad 49$ & 98 \\
$\quad$ dietitian and doctor & 47 & 94 \\
$\begin{array}{l}\text { One Nutritionist at district } \\
\text { head quarter }\end{array}$ & 49 & 98 \\
Initiative by Nutritionist & 38 & 76 \\
\hline
\end{tabular}

latest aids (ADA report 1987). Table 3, further shows that more than 88 percent of study population had suggested Ayurvedic therapy to emphasize nutrition education, mass media to act as effective disseminator and Ayurvedic personnel's to participate more regularly in various seminars, meetings and symposium.

More than 98 percent of the respondents recommended/demanded higher authorities to depute at least one dietitian at block level and one Nutritionist at district head quarters. Further, the Table 4, shows that 76 percent Ayurvedic doctors expect nutritionists to take initiative steps at their level.

\section{CONCLUSION}

Responses on therapeutic nutrition showed that the concepts of different types of diet and their recommendations for selected diseases were not known to most of the respondents. A sizable population (91\%) answered correctly the principle diet in hypertension.

More than 95 percent of the respondents possessed apt knowledge on the inclusion of milk in tuberculosis. Strained fruit juices can be given freely to patients having diarrhea was accurately reported by 84 percent of the respondents. Similarly, knowledge about exclusion and inclusion of food items was satisfactory.

The subjects when enquired about the most appropriate mode of treatment in selected diseases, the correct responses were found to be ranging from 2 percent (in case of heart attack) to 96 percent (in case of typhoid). Almost all of them considered diet as one of the important component in the treatment of selected diseases. In general, Ayurvedic doctors had favorable attitudes regarding nutrition and its counseling and were of opinion that nutrition subject be included in their curriculum of Ayurvedic therapy and a dietitian be appointed in every hospital. Majority of them do realize the importance of diet and it's counseling in medical treatment.

Finally, it can be concluded that despite of the favorable attitudes of Ayurvedic doctors towards nutrition and its counseling, the ultimate responsibility of rendering quality nutritional care services to the community rests with a team of physician and dietitian - nutritionist working in a co-ordinated manner which hitherto, has never been given its due weightage. The co-operation and support of Ayurvedic doctors in the present study is fully acknowledged.

\section{REFERENCES}

American Dietetic Association Report (ADA). 1987. "Nutrition-essential component of medical education." J. Am. Diet. Assoc., 87(5): 642-647.

Chopra, A. and W. Doiphose. 2002. "Ayurvedic medicine. Core concept, therapeutic principles, and current relevance. Med. Clin. North Am., 86(1): 75-89.

Emes, L.N., I. J. Beborah and P. T. Susan. 1994. "Nutrition education in medical schools." Am. J. Clin. Nutr., 60(5): 793-795.

Kataria, P. 1996. Nutritional Knowledge of Medical Practitioners of Udaipur City, Unpublished M.Sc. Thesis, College of Home Science, RAU, Bikaner.

Khanna, K. 1997. Textbook of Nutrition and Dietetics. New Delhi: Phoenix Publishing House.

Langseth, L. and D. H. Gemson. 1992.'The role of the physician in nutrition education." c.f. Zimmermann, M.and N. Kretchmer. 1993. "Isn't it time to teach nutrition to medical students?" Am. J. Clin. Nutr., 58(6): 828-829.

Olson, E.R. 1979. "Nutrition as a theme for the study and practice of medicine." Nutr. Rev., 37(1): !-5.

Suneza, N. and C. M. Bhat. 1985. "Nature and Extent of nutrition knowledge of medical practitioners in Hissar district." Ind. J. Nutr. Dietet., 22: 106-114

Young, A.E. 1983. "20"th Lemmo Frances Cooper Memorial lecture: Nutrition: An integral aspect of medical education." J. Am. Diet. Asso., 82(5): 482-489. 